\title{
Захворювання жінок України на інфекції, що передаються статевим шляхом як проблема первинної медичної допомоги
}

\author{
1 ДВНЗ «Ужгородський національний університет», м. Ужгород, Україна \\ ${ }^{2}$ Національна медична академія післядипломної освіти імені П.Л. Шупика, м. Київ, Україна
}

\begin{abstract}
Мета роботи: дослідити та проаналізувати захворювання жінок Украӥни на інфекиії, щуо передаються статевим иляхом в ракурсі пріоритетного розвитку первинної медичної допомоги.

Матеріали та методи. При виконанні роботи використано медико-статистичний та аналітичний методи. Матеріалами дослідження стали дані галузевої статистичної звітності за 2014-2018 роки. При проведені аналізу не враховувалися дані АК Крим, м. Севастополь та тимчасово окупованих територій Донецької і Луганської областей.

Результати. В статті представлені дані щодо захворюваності жінок Украӥни на сифіліс, гонококову та хламідійну інфекиії, урогенітальний мікоплазмоз і трихомоніаз в динаміці 2014-2018 років. Аналіз захворюваності жінок представлено в розрізі регіонів Украӥни.

Висновки. Сімейні лікарі, як лікарі першого контакту, мають проводити профілактичну роботу та виявляти захворювання на ранніх стадіях розвитку.

Ключові слова: жінки, інфекиї̈, щзо передаються статевим шляхом, захворюваність.
\end{abstract}

\section{Вступ}

нфекції, що передаються статевим шляхом (ІПСШ) - національна проблема охорони здоров'я України. За даними МО3, в Україні щорічно реєструється близько 400 тис. нових випадків сифілісу, гонореї, хламідіозу, герпесу, сечостатевого мікоплазмозу, генітального кандидозу та трихомонозу. Офіційна статистика відображає, за різними оцінками, від 30 до 40\% реальної кількості випадків ІПСШ. Це пов'язано зі збільшенням прихованих форм і тим, що окремі групи населення не отримують належної дерматовенерологічної допомоги. Отже, в Україні щорічно ІПСШ заражаються не менше 2 млн людей [7].

Особливу небезпеку становлять ІПСШ, що супроводжуються порушенням цілісності слизових оболонок (сифіліс, генітальний герпес, сечостатевий трихомоноз, сечостатевий хламідіоз, гонорея та генітальний кандидоз). Показники захворюваності на ІПСШ серед груп ризику значно вищі, ніж серед загального населення. До цих груп звичайно відносять ін'єкційних наркоманів, жінок, які займаються комерційним сексом, чоловіків, які мають статеві стосунки 3 чоловіками та ін. Перебуваючи в конфлікті 3 суспільними нормами поведінки, ці люди негативно ставляться до лікування венеричних хвороб в офіційно визнаних установах i досить часто ухиляються від лікування. Через об’єктивні причини ефективність диспансерної роботи серед таких контингентів украй низька. Найбільш дієві в даній ситуації схеми лікування в умовах амбулаторії. Специфічність характеру надання допомоги уразливим групам полягає в наступному [1-4]:

- побоювання розголосу та переслідування з боку суспільства (тому необхідна анонімність);
- труднощі в налагодженні психологічного контакту «лікар - пацієнт»;

- особливості мотивацій та поведінки, що перешкоджають багаторазовому контакту з лікарем (тому бажана одноразова зустріч);

- небажання або неможливість сплачувати за медичні послуги;

- вернення до лікаря при посередництві осіб або організацій, яким вони довіряють.

В умовах реформування системи охорони здоров'я, коли іiі пріоритетним напрямком $є$ розвиток первинної медико-санітарної допомоги на засадах загальної лікарської практики-сімейної медицини $[5,6]$ сімейні лікарі мають відігравати ведучу роль в інформуванні населення про профілактику вказаних інфекцій, їх діагностиці та лікуванні 3 Упровадженням швидкої діагностики сифілісу, гонореї, хламідіозу, герпесу, трихомонозу, що підтримує Всесвітня організація охорони здоров'я [8-10].

Мета роботи: дослідити та проаналізувати показники захворювання жінок України на інфекції, що передаються статевим шляхом в ракурсі пріоритетного розвитку первинної медичної допомоги.

\section{Матеріали та методи}

При виконанні роботи використано медикостатистичний та аналітичний методи. Матеріалами дослідження стали дані галузевої статистичної звітності за 2014-2018 роки. При проведені аналізу не враховувалися дані АК Крим, м. Севастополь та тимчасово окупованих територій Донецької і Луганської областей. 


\section{Результати дослідження та їх обговорення}

На початку дослідження були вивчені та проаналізовані дані що до захворюваності жінок України на сифіліс. Дослідження проводилося в розрізі регіонів України за період з 2014 по 2018 рр. Отримані результати наведено в табл. 1.

Наведені в табл. 1 дані вказують на те, що кількість жінок, які захворіли на сифіліс за роки дослідження скоротилася на 603 і в 2018 році склала 1128. Показник в розрахунку на 100 тис. жінок скоротився з 7,5 до 5,0.

В 2014 році найвищі показники захворюваності жінок на сифіліс були зареєстровані в Одеській $(20,5)$ та Волинській $(14,6)$ областях, а найнижчі в Луганській $(1,3)$ та Донецькій $(1,6)$ областях. Гранична різниця показника складає 15,77 разів.

В 2018 році найвищі показники захворюваності жінок на сифіліс були зареєстровані в Кіровоградській та Житомирській $($ по 11,1) областях, а найнижчі в Черкаській $(1,2)$ та Донецькій і Тернопільській (по 2,1) областях. Гранична різниця показника складає 5,28 разів.

При цьому за період дослідження показник захворюваності жінок на сифіліс в Одеській області скоротився в 2,2разу і склав 9,3, а в Луганській області зріс в 4,77 разів і склав 6,2 на 100 тис. жінок.

Далі вивчалося питання захворюваності жінок на гонококову інфекцію. Отримані результати наведено в табл. 2.

Аналіз наведених в табл. 2 даних показав на скорочення абсолютної кількості інфікованих жінок на 6433 їх кількістю в 2018 році - 1424. Показник в розрахунку на 100 тис. жінок скоротився з 9,0 до 6,3.

В 2014 році найвищі показники захворюваності жінок на гонококову інфекцію були зареєстровані в Дніпропетровській $(32,6)$ та Сумській $(18,4)$ областях, а найнижчі в Луганській $(1,3)$ та Донецькій $(1,9)$ областях. Гранична різниця показника складає 25,08 разів.

В 2018 році найвищі показники захворюваності жінок на гонококову інфекцію були зареєстровані в Дніпропетровській $(26,5)$ Кіровоградській $(15,8)$ областях, а найнижчі в Закарпатській $(0,6)$, Київській $(0,7)$, Запорізькій $(1,2)$ областях. Гранична різниця показника складає 44,17 разів.

В м. Києві, як столиці держави показник захворюваності жінок на гонококову інфекцію за період дослідження коливався в межах 1,2-1,8 на 100 тис. жінок мегаполісу.

Наступним кроком дослідження було вивчення показників захворюваності жінок на хламідійну інфекцію. Отримані результати наведено в табл. 3 .

Проведений аналіз наведених в табл. 3 даних показав на скорочення абсолютної кількості уражених хламідійною інфекцією жінок на 4146 з їх кількістю в 2018 році - 10872. Показник в розрахунку на 100 тис. жінок скоротився з 65,1 до 48,0.

В 2014 році найвищі показники захворюваності жінок на хломідійну інфекцію були зареєстровані в Одеській $(202,3)$, Херсонській $(188,1)$ та Київській $(166,4)$ областях, а найнижчі в Луганській $(3,1)$, Донецькій $(7,8)$ та Закарпатській $(11,0)$ областях. Гранична різниця показника складає 65,26 разів.

В 2018 році найвищі показники захворюваності жінок на хламідійну інфекцію були зареєстровані в Одеській $(176,4)$, Київській $(173,2)$ та Харківській $(113,9)$ областях, а найнижчі в Чернівецькій $(5,2)$, Запорізькій $(5,3)$ та Луганській $(6,2)$ областях. Гранична різниця показника складає 33,92 разів.

В м. Києві показник захворюваності жінок на хламідійну інфекцію за період дослідження коливався в межах 39,9-49,6 на 100 тис. жінок мегаполісу.

Далі вивчалися показники захворюваності жінок на трихомоніаз. Отримані результати наведено в табл. 4.

Проведений аналіз наведених в табл. 4 даних показав на скорочення абсолютної кількості уражених на трихомоніаз жінок на 13162 з їх кількістю в 2018 році 32844. Показник в розрахунку на 100 тис. жінок скоротився $з$ 199,5 до 145,0.

В 2014 році найвищі показники захворюваності жінок на трихомоніаз були зареєстровані в Житомирській $(468,4)$, Одеській $(398,2)$ та Миколаївській $(380,5)$ областях, а найнижчі в Донецькій $(29,3)$ та Луганській $(30,6)$ областях. Гранична різниця показника складає 15,98 разів.

В 2018 р. найвищі показники захворюваності жінок на трихомоніаз були зареєстровані в Одеській $(331,0)$, Житомирській $(284,9)$ та Херсонській $(297,6)$ областях, а найнижчі в Тернопільській $(48,2)$ та Донецькій $(61,6)$ областях. Гранична різниця показника складає 6,87 разів.

В м. Києві, як столиці держави показник захворюваності жінок на трихомоніаз за період дослідження коливався в межах 27,3-42,8 на 100 тис. жінок мегаполісу.

Наступним кроком дослідження було вивчення та проведення аналізу показників захворюваності жінок України на урогенітальний мікоплазмоз. Отримані результати наведено в табл. 5.

Проведений аналіз наведених в табл. 5 даних показав на скорочення абсолютної кількості уражених на урогенітальний мікоплазмоз жінок на 4033 з їх кількістю в 2018 році 18448 осіб. Показник в розрахунку на 100 тис. жінок скоротився з 97,5 до 81,4.

В 2014 році найвищі показники захворюваності жінок на урогенітальний мікоплазмоз були зареєстровані в Харківській $(410,5)$, Київській $(168,8)$ та Хмельницькій $(159,4)$ областях, а найнижчі в Луганській $(30,6)$, Житомирській $(3,7)$, Сумській $(4,4)$ областях. Гранична різниця показника складає 164,2 рази.

В 2018 році найвищі показники захворюваності жінок на урогенітальний мікоплазмоз були зареєстровані в Харківській $(241,1)$, Одеській $(200,3)$ та Донецькій $(200,2)$ областях, а найнижчі в Житомирській $(3,0)$, Сумській $(4,6)$ та Закарпатській $(4,9)$ областях. Гранична різниця показника складає 80,37 разів.

В м. Києві, як столиці держави показник захворюваності жінок на урогенітальний мікоплазмоз інфекцію за період дослідження коливався в межах 156,4185,8 на 100 тис. жінок мегаполісу, що перевищує середні показники по країні. 


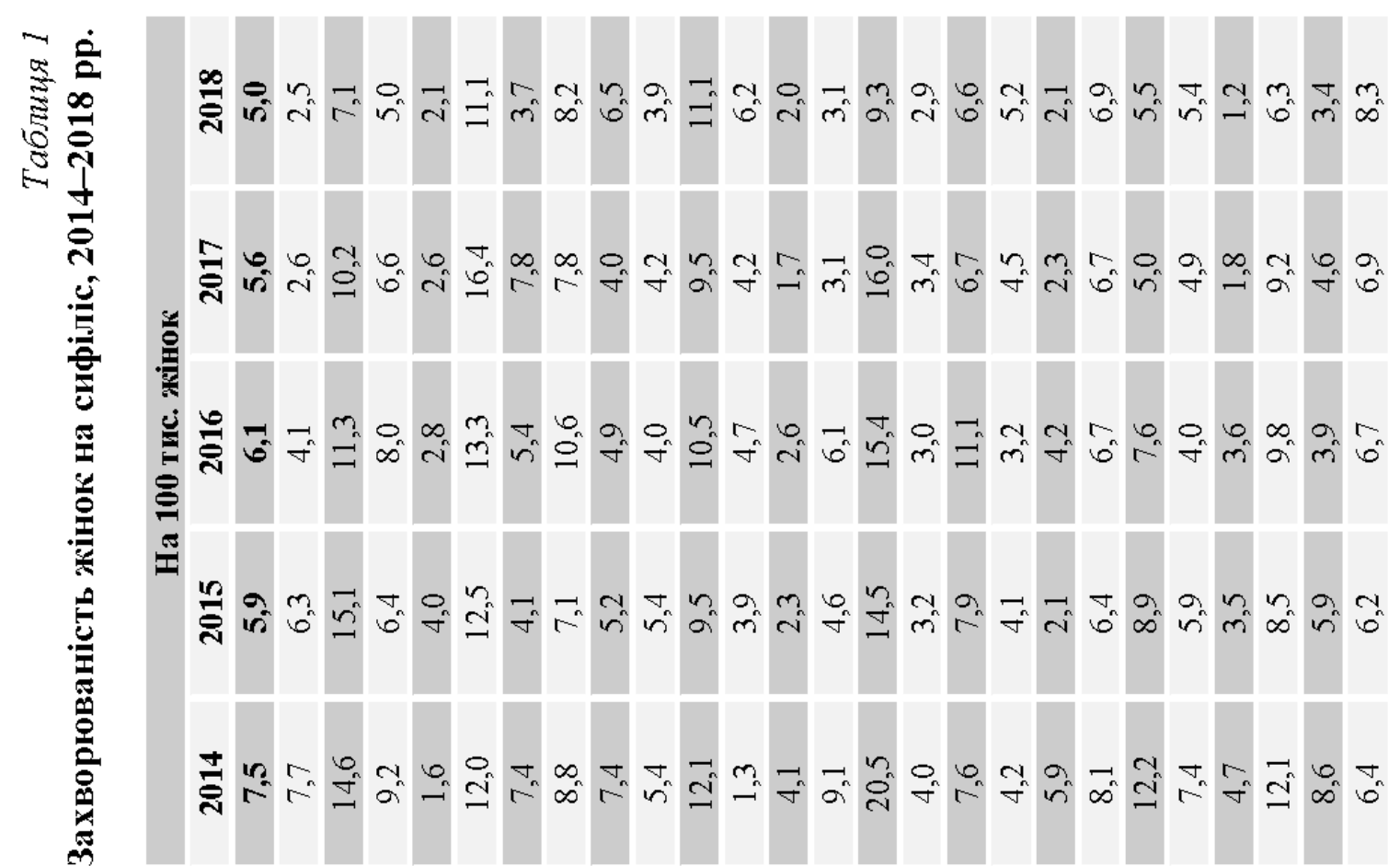

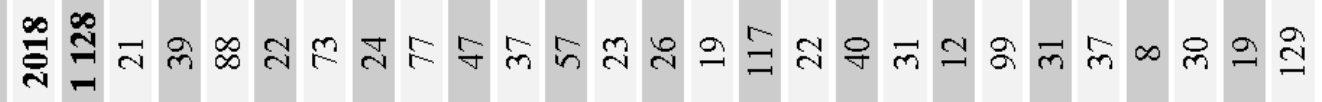

독

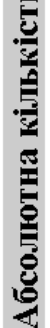

귐

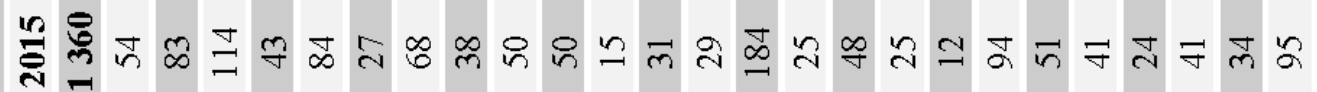

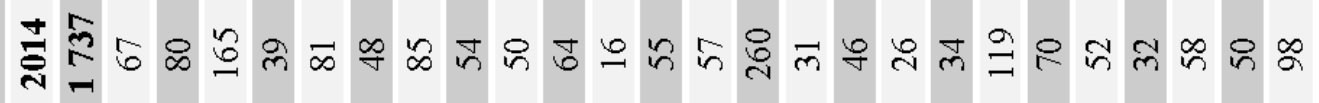

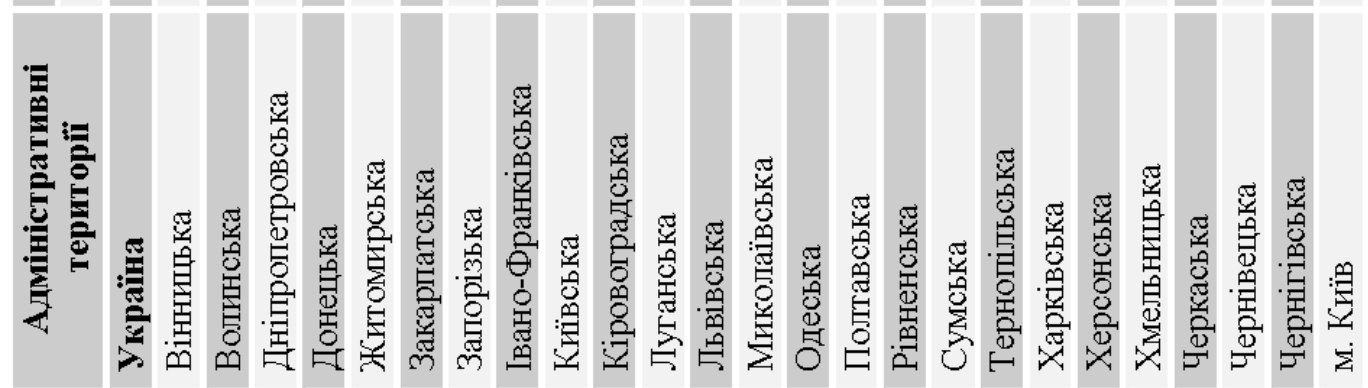




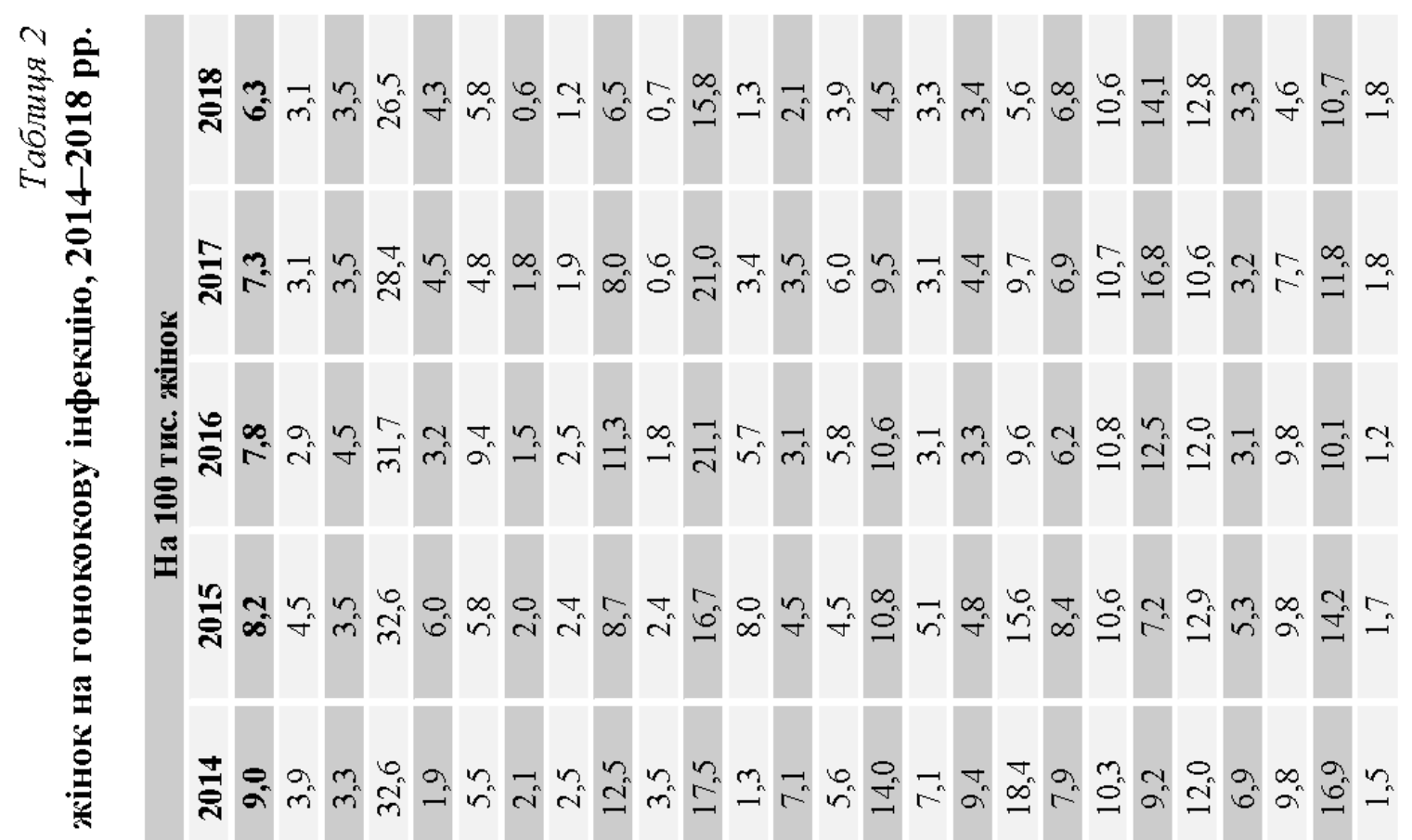

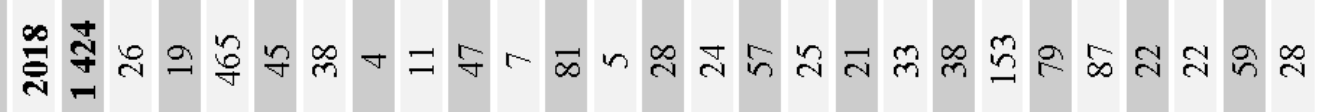

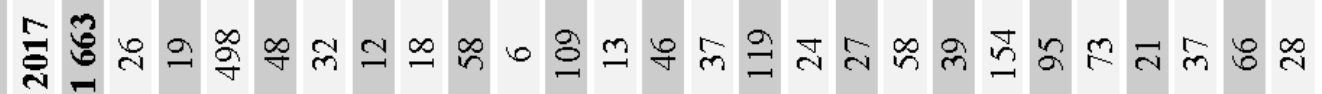

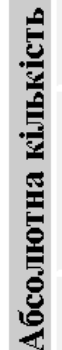

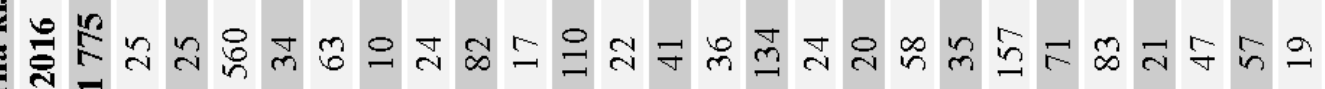

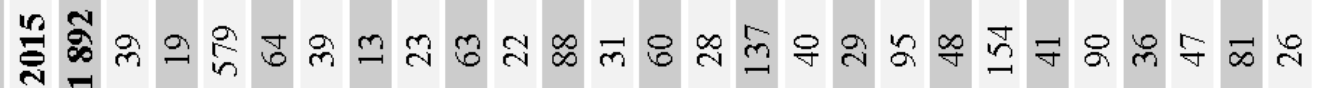

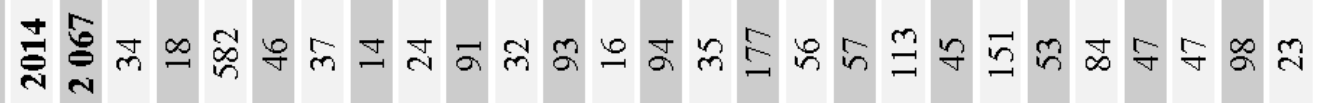

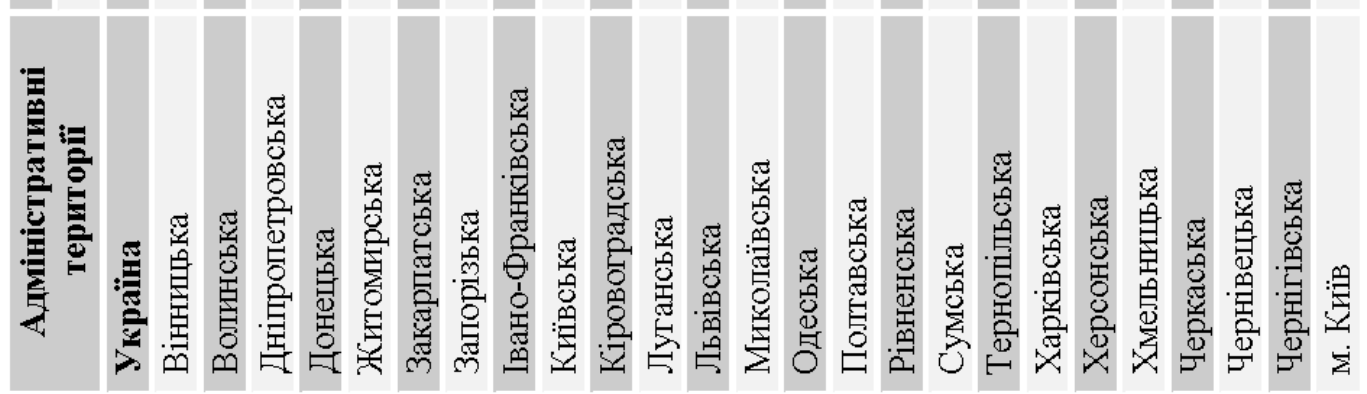




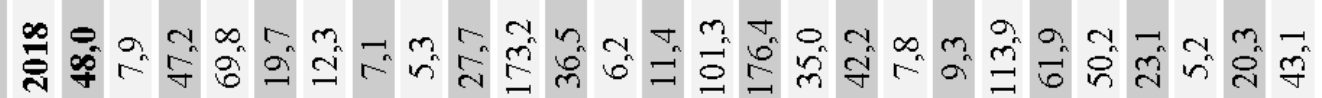

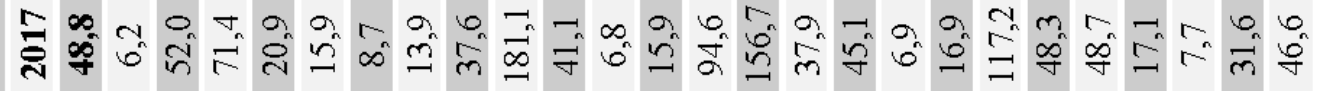
章

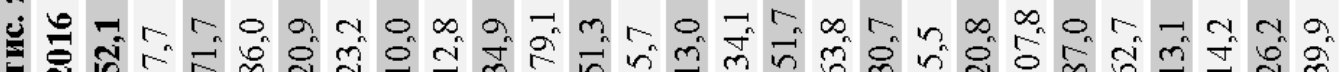

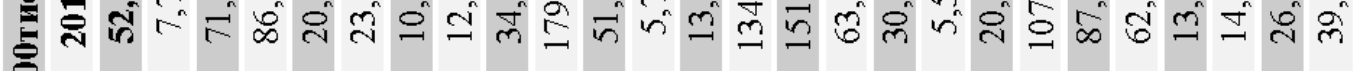

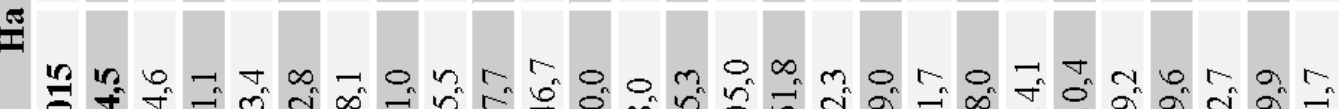

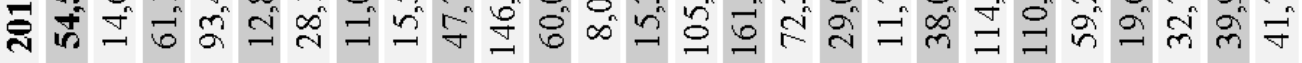

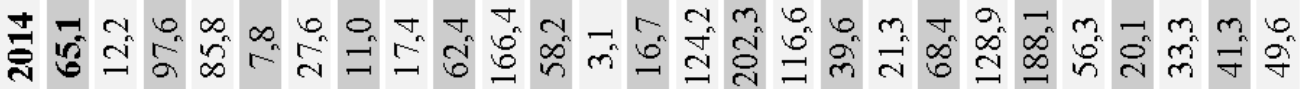

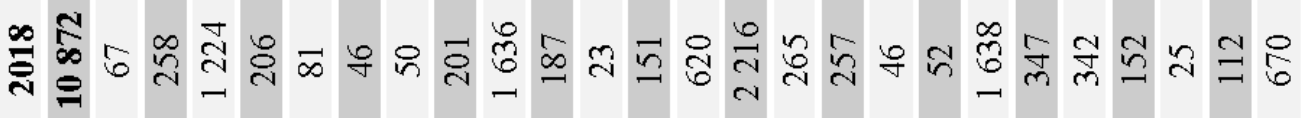

코를

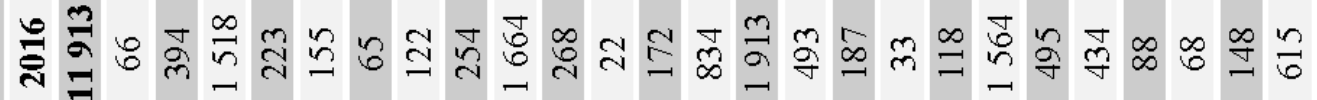

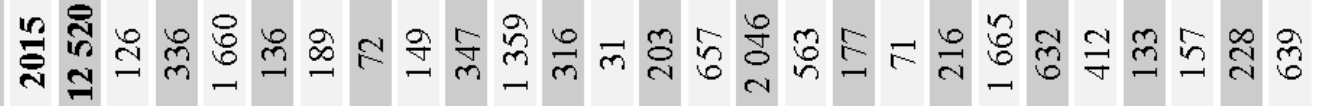

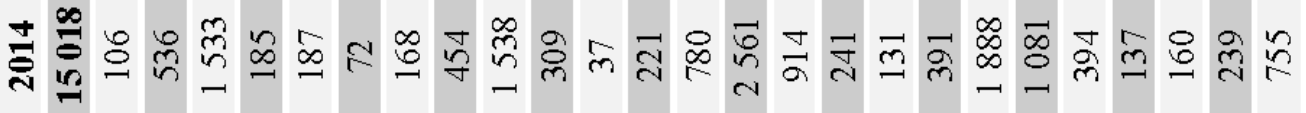

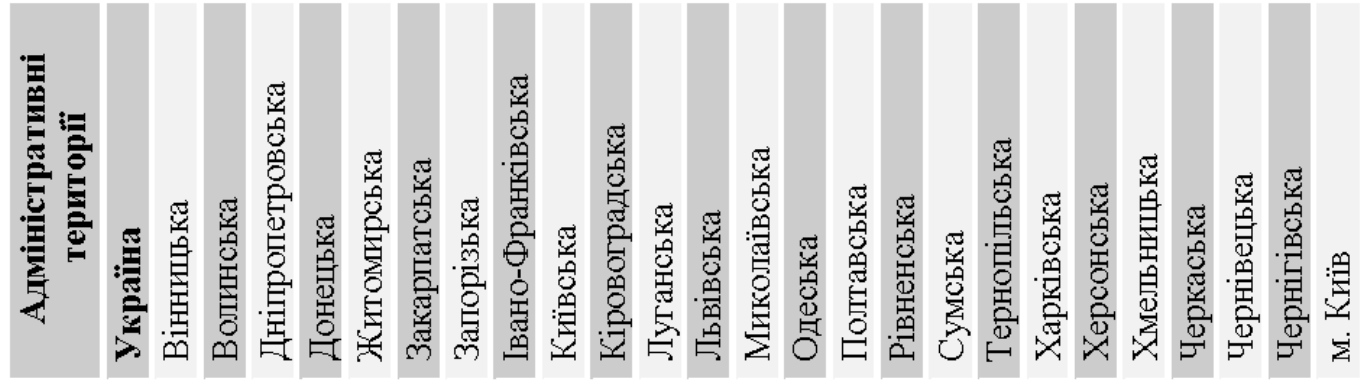




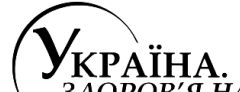

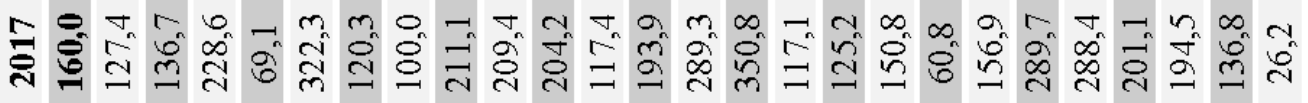

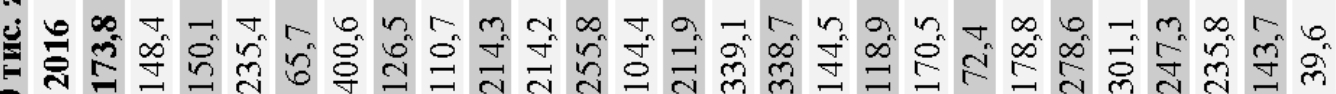
8

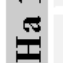

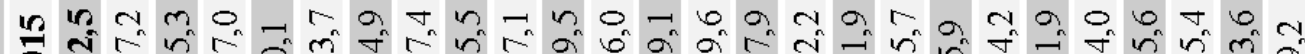

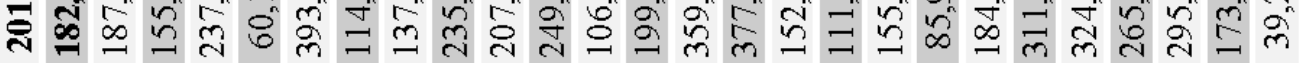

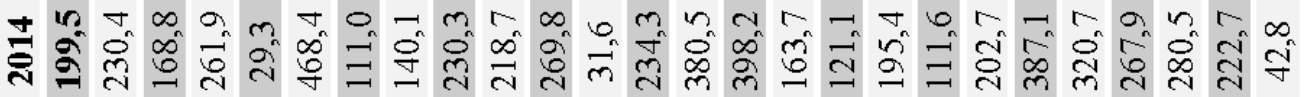

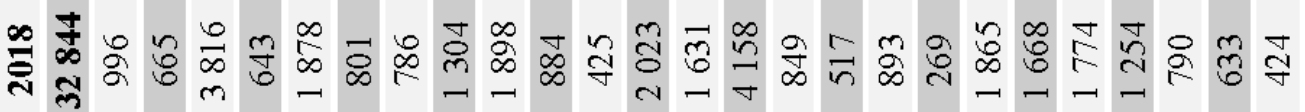

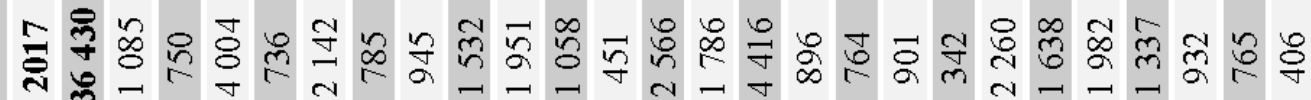
政

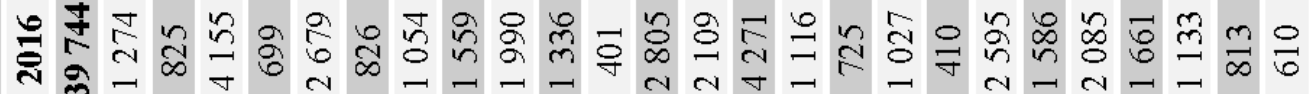

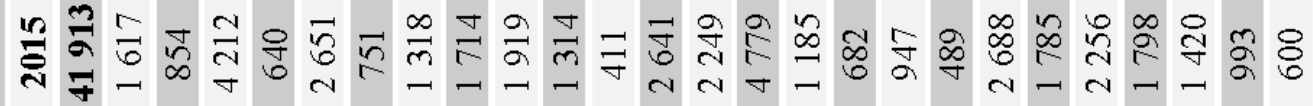

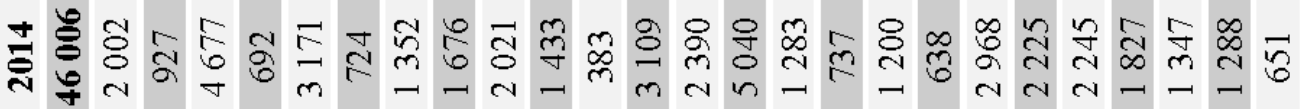

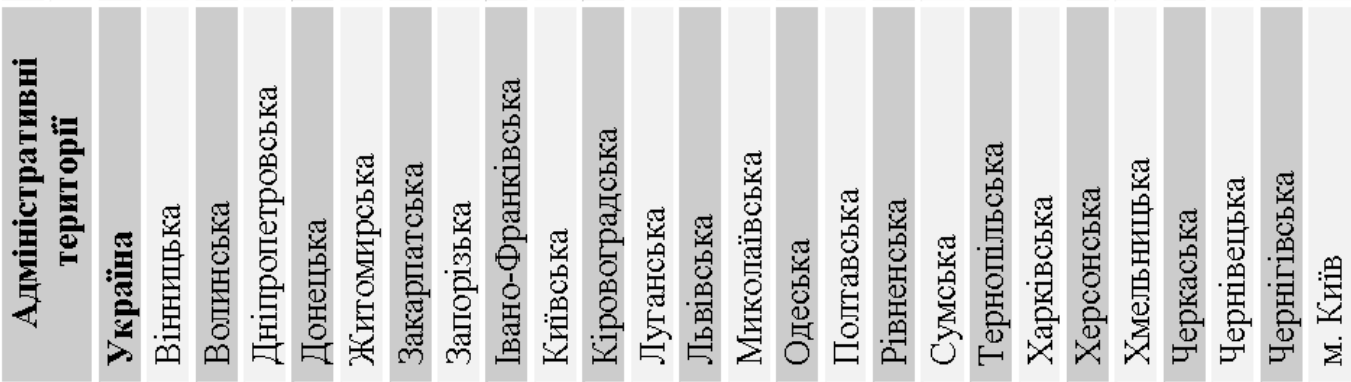




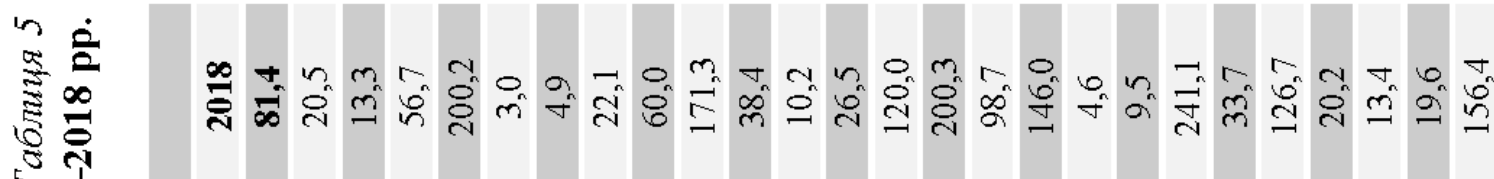

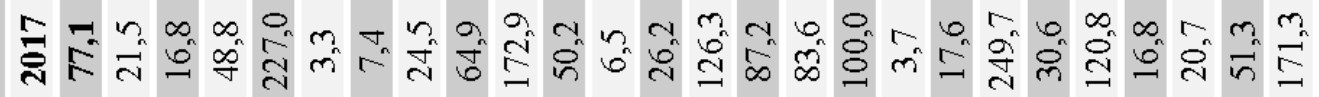 参

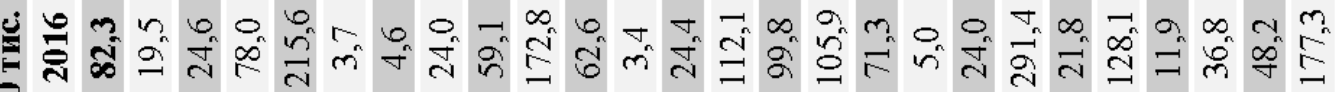

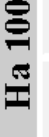

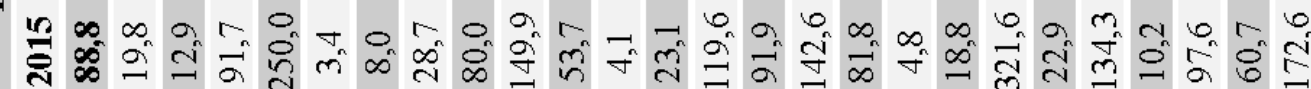

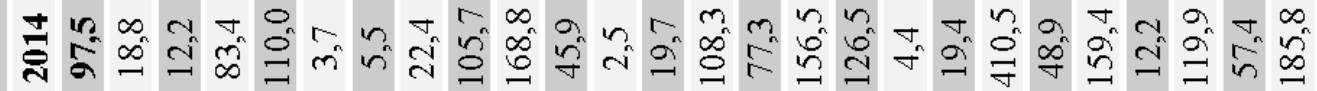

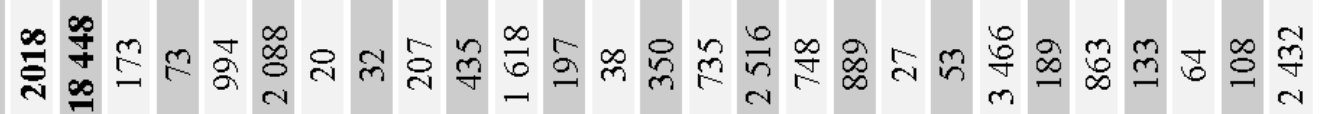

두ㄹㅠㅠ 党

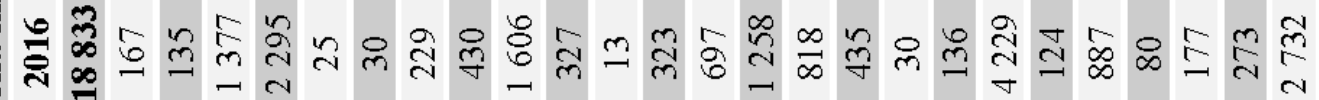

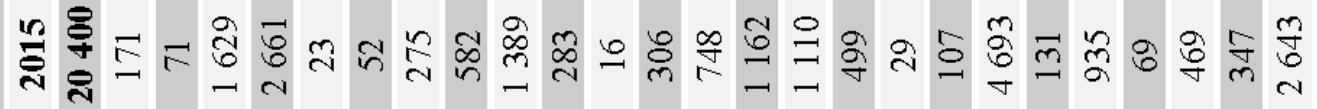

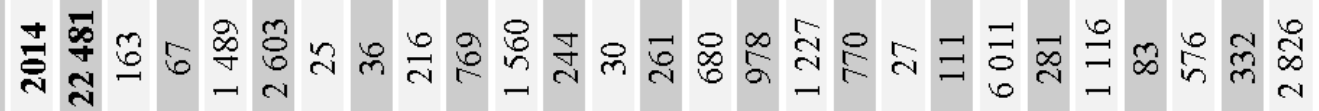

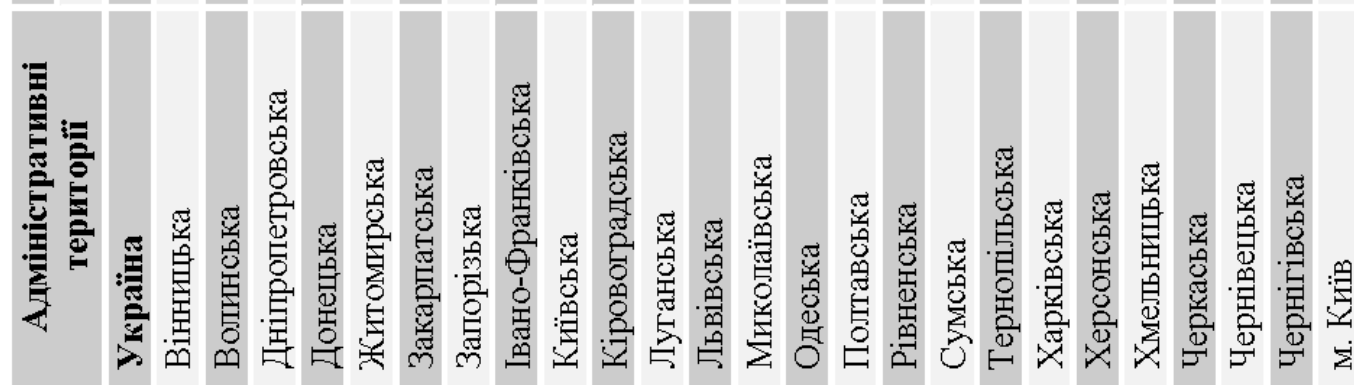




\section{Висновки}

При вивченні показників захворюваності жінок України на хвороби, що передаються статевим шляхом так як сифіліс, гонококову та хламідійну інфекції, урогенітальний мікоплазмоз і трихомоніаз в динаміці 2014-2018 років встановлено, що рівень їх за роки дослідження знизився. При цьому, в розрізі регіонів
України за показниками захворюваності за всіма хворобами виявлені статистично значущі відмінності.

Перспективи подальших досліджень пов'язані 3 вивченням надання медичної допомоги жінкам 3 хворобами, що передаються статевим шляхом сімейними лікарями.

\section{Література}

1. Запорожан В.М., Аряєв М.Л. ВІЛ-інфекція і СНІД. - К.: Здоров’я, 2004. - 636 с.

2. Консультирование в связи с ВИЧ/СПИД: Учеб. пособие / Т.В. Проценко, И.В. Куценко, О.А. Проценко. Донецк, 2002. - 64 с.

3. Основы консультирования по вопросам репродуктивного сексуального здоровья / Бондаренко С.Г., Ворник Б.М., Гарнец О.Н., Квашенко В.П. и др. - К., 2004. - 264 с.

4. Проценко О.А., Кигель М.Г., Куценко И.В. и соавт. Консультирование по вопросам ИППП/ВИЧ/СПИДа и психоэмоциональная поддержка ВИЧ-позитивных осужденных в условиях пенитенциарной системы в Донецком регионе. - Донецк, 2005. - 63 с.

5. Слабкий Г.О. Кадрове забезпечення сімейної медицини в Україні/ Розвиток первинної медичної допомоги на засадах сімейної медицини. - Київ, 2018. - С. 109-121.

6. Слабкий Г.О. Розвиток мережі закладів охорони здоров'я загальної лікарської практики - сімейної медицини / Розвиток первинної медичної допомоги на засадах сімейної медицини. - Київ, 2018. - С. $104-108$.

7. Степаненко B.I. Стан та проблеми дерматовенерологічної служби в Україні // Дерматологія та венерологія. - 2004. - № 4(26). - С. 10-15.

8. Широбоков В. П., Дзюблик І.В., Вороненко С.Г. та ін. Застосування швидких тестів у лабораторній діагностиці інфекційних хвороб (методичні рекомендації з наказом МОЗ України № 467 від 23.09.2004). K., 2004. - 32 c.

9. Benzaken A.S., Galban E.G., Antunes W. et al. Diagnosis of gonococcal infection in high risk women using a rapid test // Sexually Transmitted Infections. - 2006. - Vol. 82. - P. 26-28.

10. Herring A.J., Ballard R.C., Pope V. et al. A multi-centre evaluation of nine rapid, point-of-care syphilis tests using archived sera // Sexually Transmitted Infections. - 2006. - Vol. 82. - P. 7-12.

Дата надходження рукопису до редакиї: 23.09.2019 р.

\section{Women morbidity for sexually transmitted infections in Ukraine as a problem of primary medical care}

\section{Slabkiy G.O., Myronyuk I.S., Shcherbinska O.S. Uzhhorod National University National Medical Academy of Postgraduate Education named after P.L. Shupik}

Goal of research: to study and analyze the morbidity of women in Ukraine for sexually transmitted infections in the frames of priority development of primary medical care.

Materials and methods. Medico-statistical and analytical methods were applied in the course of research. The data of sectoral statistical reporting for the years 2014-2018 were used as the materials of research. The data from Crimea,
Sevastopol and temporarily occupied territories of Donetsk and Luhansk regions was not taken into account when the analysis was carried out.

Results. The article presents the data on the morbidity of women in Ukraine for syphilis, gonococcal and chlamydiosis, urogenital mycoplasmosis and trichomoniasis in the dynamics of the years 2014-2018. The analysis of women's morbidity is represented by regions of Ukraine.

Conclusions. Family doctors, as first-contact physicians, should carry out preventive work and detect diseases in early stages of development.

Key words: women, sexually transmitted infections, morbidity. 
Заболеваемость женщин в Украине инфекциями, передающимися половым путем, как проблема первичнной медицинской помощи

Слабкий Г.А., Миронюк И.С., Щербинская О.С. Ужгородский национальный университет Национальная медицинская академия последипломного образования им. П.Л. Шупика

Цель работы: исследовать и проанализировать заболеваемость женщин в Украине инфекциями, передающимися половым путем, в ракурсе приоритетного развития первичной медицинской помощи.

Материалы и методы. При выполнении работы использовались медико-статистический и аналитический методы. Материалами исследования стали данные отраслевой статистической отчетности за 2014-2018 годы. При проведении оккупированных территорий Донецкой и Луганской областей.

Результаты. В статье представлены данные о заболеваемости женщин в Украине сифилисом, гонококковой инфекцией, хламидиозом, урогенитальным микоплазмозом и трихомониазом в динамике 2014 2018 годов. Анализ заболеваемости женщин представлено в разрезе регионов Украины.

Выводы. Семейные врачи, как врачи первого контакта, должны проводить профилактическую работу и выявлять заболевания на ранних стадиях развития.

Ключевые слова: женщины, инфекции, передающиеся половым путем, заболеваемость.

\section{Відомості про авторів}

Слабкий Г.О. - д.мед.н., проф., завідувач кафедри наук про здоров’я ДВНЗ «Ужгородський національний університет»; 88000, пл. Народна, 3, м. Ужгород, Закарпатська обл., Україна.

Миронюк I.C. - Д.мед.н., доц., декан факультету здоров’я та фізичного виховання ДВНЗ «Ужгородський національний університет»; 88000, пл. Народна, 3, м. Ужгород, Закарпатська обл., Україна.

Щербинська О.С. - к.мед.н., Національна медична академія післядипломної освіти імені П.Л. Шупика; 04112, м. Київ, вул. Дорогожицька, 9. 